\title{
The study of technology as a field of knowledge in general education: historical insights and methodological considerations from a Swedish case study, 1842-2010
}

\author{
Jonas Hallström, Magnus Hultén and Daniel Lövheim
}

\section{Linköping University Post Print}

\section{Tweet}

N.B.: When citing this work, cite the original article.

The original publication is available at www.springerlink.com:

Jonas Hallström, Magnus Hultén and Daniel Lövheim, The study of technology as a field of knowledge in general education: historical insights and methodological considerations from a Swedish case study, 1842-2010, 2014, International journal of technology and design education, (24), 2, 121-139.

http://dx.doi.org/10.1007/s10798-013-9252-x

Copyright: Springer Verlag (Germany)

http://www.springerlink.com/?MUD=MP

Postprint available at: Linköping University Electronic Press

http://urn.kb.se/resolve?urn=urn:nbn:se:liu:diva-106569 


\title{
The Study of Technology as a Field of Knowledge in General Education: Historical Insights
} and Methodological Considerations from a Swedish Case Study, 1842-2010

Jonas Hallström, Magnus Hultén and Daniel Lövheim

Hallström and Hultén: Department of Social and Welfare Studies, Linköping University, 581 83 Linköping, Sweden. E-mail: jonas.hallstrom@liu.se

Lövheim: Department of Education, Stockholm University, 10691 Stockholm, Sweden.

\begin{abstract}
Today, technology education in Sweden is both a high-status and a low-status phenomenon. Positive values such as economic growth, global competitiveness and the sustainability of the welfare state are often coupled with higher engineering education and sometimes even upper secondary education. Negative values, on the other hand, are often associated with primary and lower secondary education in this subject. Within the realm of technology education at such lower levels of schooling in Sweden, different actors have often called for reformed curricula or better teacher training, owing to the allegedly poor state of technology education in schools. Recurring demands for a change in technology education are nothing unique from an historical point of view, however. In fact, the urge to influence teaching and learning in technology is much older than the school subject itself. The aim of this article is to describe and analyse some key patterns in technology education in Swedish elementary and compulsory schools from 1842 to 2010 . This study thus deals with how technological content has developed over time in these school forms as well as how different actors in and outside the school have dealt with the broader societal view of what is considered as important knowledge in technology as well as what kind of technology has particular significance. The long period of investigation from 1842 to 2010 as well as a double focus on technology as scattered educational content and a subject called Technology make it possible to identify recurring patterns, which we have divided into three overarching themes: Technological literacy and the democratic potential of technological knowledge, The relationship between school technology and higher forms of technology education and The relationship between technology and science.
\end{abstract}

Keywords: technological literacy, technological knowledge, history, curriculum, science 
Today, technology education in Sweden is both a high-status and a low-status phenomenon. Positive values such as economic growth, global competitiveness and the sustainability of the welfare state are often coupled with higher engineering education and sometimes even upper secondary education. Technology can, in this context, turn into a straightforward, even apolitical, aspect of society; it is seen as a self-evident and positive force (cf. Ingelstam 1978; 2013).

Negative values, on the other hand, are often associated with primary and lower secondary education in this subject. Within the realm of technology education at such lower levels of schooling in Sweden, different actors have often called for reformed curricula or better teacher training, owing to the allegedly poor state of technology education in schools. A Swedish governmental committee - the Technology Delegation (Teknikdelegationen) appointed in 2008 to "encourage greater interest in mathematics, natural sciences, technology and ICT", ${ }^{1}$ even wanted a complete overhaul of the Technology subject in compulsory school, grundskolan (Teknikdelegationen 2010, p. 15):

The [technology] subject has a very weak position within teacher education and there are few teachers with a degree in technology. In school organisation the subject is often hidden among the natural science subjects and the subject's priority is low among the school leadership and politicians. The identity of the technology subject is not clear to pupils or the general public. According to an investigation by the Technology Delegation ninth-graders make no connection between the technology subject in school and future higher education and career (Teknikdelegationen 2010, p. 114).

Recurring demands for a change in technology education are nothing unique from an historical point of view. In fact, the urge to influence teaching and learning in technology is much older than the school subject itself. The example of Sweden shows that Technology was introduced as a mandatory subject in general education in the beginning of the 1980s, but that school technology is actually a much older phenomenon. As early as the $19^{\text {th }}$ century, one can identify educational content that contemporaries sometimes defined as "technology", but which was integrated with other traditional subjects. At the time of the

\footnotetext{
${ }^{1}$ All translation from Swedish into English has been carried out by the authors.
} 
introduction of the Swedish elementary school system (folkskolan) in the 1840s, for instance, there were textbooks in Natural science that included sections on technology (Technologie). In the early $20^{\text {th }}$ century, there were also demands for "technological literacy [bildning] for each and every one", which primarily alluded to the children of workers who went to elementary school.

There are obvious disadvantages to studying the history of education by looking at various school subjects because many historical events, processes and practices may remain undiscovered. It would then be impossible to talk about school technology before the creation of the subject Technology. However, together with a modern, broader definition of technology, the above examples make it possible to look beyond a traditional set of school subjects. In this way, we may identify "technology" content in historical practices (that is, school subjects) that have not been labelled with the word technology. At the same time, this approach of projecting modern definitions on the past also requires care regarding possible interpretations.

The aim of this article is to describe and analyse some key traits or patterns in technology education in Swedish elementary and compulsory schools from 1842 to $2010 .^{2}$ This study deals with how technological content has developed over time in these school forms, as well as how different actors in the school (teachers, principals, teacher educators, etc.) and outside the school (e.g., engineers) have related to the field of school technology, for example what kind of technology they have considered important for school and why. The long period of investigation as well as the double focus on technology as scattered educational content and a subject called Technology make it possible to identify recurring patterns, which we have divided into three overarching themes.

\section{Studying school technology as an historical phenomenon}

When technology as a school subject was established and introduced in Sweden during the second half of the $20^{\text {th }}$ century, it did not emerge out of nowhere. Instead traditions, practices and discourses that until then had been largely hidden were made visible through

\footnotetext{
${ }^{2}$ All three authors have contributed equally to the data collection, analysis and writing of this article. The research on which the article is based has also partly provided material for Hallström et al. (2013).
} 
the new subject. As implied above, the choice of the period of investigation requires a certain approach to what can be said about the knowledge content in schools. It demands a perspective that enables historians to move beyond subject labels, curriculum documents and timetables.

In order to carry out this kind of study, we employ a hermeneutic method and analyse a rich selection of historical material in the form of parliamentary papers (official reports, government bills, parliamentary debates), material from central school authorities such as the National Board of Education (Skolöverstyrelsen, formed in 1920, which executed and followed up reforms and took care of in-service education, etc.) as well as professional journals, newspapers, textbooks, educational films, curricula, educational policy documents and interview transcripts from the period of investigation.

In the interpretation and analysis of the material, we characterise technology and its various dimensions in two ways. The first is to identify how actors at the time used the term "technology" and gave it meaning in an educational context. An obvious challenge in the analysis is that the term technology has changed a lot since the early 20th century, which Schatzberg (2006) also points out:

[Technology] attained the status of "keyword" only in the 1930s, and [...] before this time, issues that historians now discuss in terms of technology were framed in such terms as useful arts, manufacturing, industry, invention, applied science, and the machine. In other words, when historians now address "attitudes toward technology" before 1930, they are employing an analyst's category not used by the historical actors themselves (p. 486).

We address this problem by also relying on encyclopaedias of the time, most notably the dictionary Nordisk familjebok $(1891 ; 1919)$. This helps in analysing the meaning of the term, when it cannot be directly derived from its actual use. ${ }^{3}$ In Swedish, just as in other Germanic languages, technology is translated as both teknik and teknologi. In the early $20^{\text {th }}$ century, the Swedish concept of teknik had a similar meaning to the English equivalents "useful arts, manufacturing, industry, invention, applied science, and the machine" (Schatzberg 2006, p.

\footnotetext{
${ }^{3}$ Encyclopaedias are not always the best sources of how concepts were actually used, however (Schatzberg 2006, p. 491; Oldenziel 1999, p. 184).
} 
486). However, the Swedish concept was also increasingly connected to engineering, which can be seen in the 1919 edition of Nordisk familjebok (1919).

A second way of dealing with the definition of technology is to rely on a modern, broader characterisation. Historian of technology Thomas P. Hughes writes: "Technology is messy and complex. It is difficult to define and to understand. In its variety, it is full of contradictions, laden with human folly, saved by occasional benign deeds, and rich with unintended consequences [...] Few experienced practitioners, historians, and social scientists try to inclusively define technology" (Hughes 2004, p. 1-2). Thus, there is no universally accepted definition of technology, but an important starting point is that technology has to do with something material, that is, the designed or human-built world and how we as humans relate to it (ibid.; Blomkvist and Kaijser 1998).

Having pointed this out, as a modern characterisation of what technology is, we partly refer to Mitcham's (1994) definition of technology, which encompasses various dimensions of technology that abounded in the late $19^{\text {th }}$ and first half of the $20^{\text {th }}$ century, but were not necessarily defined as such by the historical actors. Mitcham's fourfold description of technology is as volition, knowledge, activity and object. ${ }^{4}$ At the same time, we can conclude that, for example, the systems perspective is largely missing. Ever since the 1970s, historians and sociologists of technology have studied technology as systems, since technology not only consists of separate objects but also large technological systems with other structures, functions and dynamics than the single objects by themselves (Hughes 1987; Klasander 2010). The so-called Actor Network Theory also illuminates the fact that technology can have the ability to "act" together with human actors in actor-networks, in which these "actants" constitute driving forces in the development of technology together with humans (Latour 1987; 1999; Hård and Jamison 2005). Another question when defining technology has concerned the relationship between technology and science. Some researchers assert

\footnotetext{
${ }^{4}$ Technology as volition comprises the will, wish, intention or power that starts the technological activity. Technology as knowledge consists of the skills and knowledge necessary to perform the technological activity. Technological activity is the activity performed to reach a goal or fulfil wishes, either by designing and making or by using technology. In everyday language, technology is used mainly when talking about an object, that is, a technological artefact. This object is used in a technological activity or it is a result of this. Technology as volition is supposed to be fulfilled by the artefact that results from the activity (Mitcham 1994, p. 137-160; cf. Lindqvist 1987).
} 
that technology has its foundations in scientific knowledge, whereas others claim that technology is a knowledge domain of its own (Arthur 2009; Hansson 2002).

The research field that this study relates to is tentatively called the history of technology in general education. Even though this study mainly concerns primary and lower secondary education, we also count upper secondary education as part of the field as the international research includes both primary and secondary education. In comparison with, for instance, the history of science or mathematics education, there has been relatively little research on the history of technology education (McCulloch 1987; Rudolph 2008). Characteristic of many studies is that they connect to the history of education, the history of science as well as technology education research. Consequently, the field is broad and research problems as well as empirical material exist in tension between several quite disparate domains. As such, there are generally cross-disciplinary approaches among researchers, inspired by historical, philosophical, sociological, technological as well as educational methods and theories. For instance, David Layton, Edgar Jenkins, Karen Zuga, John Pannabecker and Stephen Petrina have pioneered the field thanks to their connections to both the history of education and technology education (Layton 1994; Pannabecker 1995; Jenkins 1997; Zuga 1997; Petrina 1998).

There are a few larger themes that have dominated research that this article relates to. A first theme consists of ideas that have been the basis for and have anticipated technology in general education, often with researchers going back to the Enlightenment, industrialisation and the origins of modern schooling from the late $18^{\text {th }}$ century onward (e.g., Pannabecker 1994; Chafy 1997). A second theme constitutes various precursors to technology in general education, for instance, American Industrial arts or Scandinavian Educational sloyd, although researchers have not always had school technology as their point of departure (e.g., Foster 2011; Herschbach 1996; Hallström 2009; 2011). A third theme concerns why and how the subject Technology originated in general education, which has sometimes also included precursors (McCulloch et al. 1985; Elgström and Riis 1990; de Vries and Mottier 2006; Hultén 2012; Hallström et al. 2013). In this article, we primarily relate and contribute to the second and third themes.

Technological literacy (Bildung) and the democratic potential of technological knowledge 
There has long been a discourse on technological knowledge that has to do with its potential for enriching and boosting people's everyday lives and making them more effective as citizens. Today, this is called technological literacy in the English-speaking world (Jenkins 1997; ITEEA 2000), but in late $19^{\text {th }}$ and early $20^{\text {th }}$ century Sweden, this was instead connected to the German concept of Bildung. The Swedish allmänbildning (or merely bildning) was derived from the German word Bildung, meaning comprehensive, all-round knowledge that fundamentally transforms human beings into mature, independent citizens (Högnäs 2001). In conjunction with technological knowledge, words like praktisk bildning, teknisk bildning and teknisk allmänbildning appeared in Swedish professional journals of teachers and engineers, at least from the early $20^{\text {th }}$ century.

However, although the word bildning was seldom used as early as the 19th century, arguments promoting a basic, all-round kind of technological knowledge could be seen, for example, concerning Science textbooks for elementary schools. The textbook writer J.F. Schlez motivated the section on "Technologie" in Science by reasoning that, "it is hardly understandable how an otherwise sensible person can live his entire life drinking from a glass, looking through windows, viewing himself in the mirror and putting the glasses on his nose, without even asking out of what and how the glass was made" (Schlez 1846, p. 210).

When the concept of teknisk or praktisk bildning became more widespread in the early $20^{\text {th }}$ century, it was intertwined with class issues; these were tumultuous years preceding the introduction of universal suffrage in Sweden in 1918-1921. From the point of view of the working class, technology education in a more systematic sense was difficult to obtain since it was delivered at technical upper secondary schools and technical universities such as the Royal Institute of Technology (KTH), which were primarily available to the middle and upper classes. It seems, therefore, that technological literacy - teknisk or praktisk bildning - was primarily lacking in the elementary school due to the limited and scattered technology education that was carried out there, primarily in Educational sloyd. One anonymous writer in one of the teacher journals, Svensk läraretidning, thought that it was imperative that technology education be made available for the greatest possible number of people, particularly manual workers. However, somewhat dejectedly, he concluded that the Swedish school system was designed to "obstruct the obtaining of technological literacy [teknisk 
bildning] for each and every one who does not belong to the wealthier classes" (Vår praktiska bildningslinje 1902, p. 492).

In the first decades of the $20^{\text {th }}$ century, Sweden grew more and more industrialised and technological artefacts and systems increasingly came to permeate various parts of society, at the same time as democratisation was dawning with the advent of universal suffrage. Parallel to this development, technological literacy increasingly became part of the new civic education in elementary school and the so-called continuation school (fortsättningsskola). In Sweden, the new subjects introduced in 1918-19 were called Hembygdskunskap, Home geography, for elementary school and Medborgarkunskap, Civic education, for continuation school. These subjects were introduced under the influence of similar subjects in, for example, Germany (Heimatkunde) and the United States (Home geography) (Barton 2009).

What would be termed technological literacy today was not very prominent from the beginning. By using, for instance, Mitcham (1994) as a tool of analysis, we can see that it was above all Home geography that included a lot of technological objects and activities associated with the local region already from its inception as an obligatory subject in 1919. Along with an increased societal dependence on technology in different forms, even civic education was eventually affected by the technological development from around 1930 onward.

In the early 1930s, the engineer Arvid Centervall made a speech entitled, "Are our people interested in technological literacy [teknisk bildning]?", in which he questioned a notion that was commonly held in early $20^{\text {th }}$ century Sweden, namely, that Swedes had a strong natural aptitude for all things technical (cf. Elzinga et al. 1998; Mellström 2009):

It is not unusual for both younger and older citizens to become very enthusiastic over, for instance, new innovation, and instantly want to know everything about it. It soon becomes apparent, however, that this interest is very superficial. In reality one should rather compare this with the joy and curiosity of children over new toys. This hardly constitutes a deeper thirst for knowledge, because as soon as they have learnt which button to press in order for the device to "go" [...] they usually feel satisfied. When trying to comprehend what is going on, and taking pains to understand why one should do this or that, there is generally a lack of both patience and power of concentration. 
A shallow interest [...] certainly exists to a great extent, and it is sufficient when it comes to using and taking advantage of technological progress. However, it is not enough for a nation that wants to carry on constructive activities in this area [...] This requires a deeper interest, an interest that really tries to penetrate the nature of things (Centervall 1932, p. 5).

Centervall went on to say that it was unfortunate that so many wanted to take advantage of industrial products but still considered industry itself uninteresting. This was even true of "textbooks in civic education" (p. 6), by which he probably meant Värner Rydén's classic textbook Medborgarkunskap för fortsättnings- och andra ungdomsskolor, but perhaps also Nils Helger's Medborgarbok för ungdomsskolor:

While in our public schools we learn names and so on of various cities, plants and animals, mountains and rivers in foreign countries that we will never see, the pocket watch, telephone, car, railway engine, printing presses, textile and agricultural machines [...] remain secret mysteries to most of us, despite their great practical significance (ibid., p. 6).

Swedish society was being transformed as regards industry and technology on a grand scale in the 1920s, although this process slowed down somewhat during the depression of the 1930s. Nonetheless, it is likely that, at least regarding Civic education, Centervall (1932) was right to say that modern industry was still so young in Sweden that it had not yet made an impact on the emerging school teaching about society and civic life.

Apart from industry, however, greater attention was focused on technical issues in civic education in the early 1930s, facilitated by the focus on the local region that many stakeholders advocated. The civic issues in the subject were thereby influenced by technology and this was mirrored in curricula and textbooks. This involved, however, not the emergence of technology education per se, but rather civics as it was affected by technology. In the late 1960s, the technology content of Home geography in compulsory school became even more explicit by the introduction of "technical phenomena in our everyday lives" ("tekniska företeelser i vardagslivet") in the national curriculum (Lgr 69 1969, p. 180). 
In the early 1960s, there was for the first time in Sweden a technology subject in general education, Technological orientation (Teknisk orientering), which was not mandatory but designed primarily for boys who would neither go on to higher education nor do a purely vocational course, a group of pupils which belonged to what in the USA was called "the new 50 percent" owing to the size of this group. This was not a subject aimed at technological literacy/Bildung, however, because it was rooted in a vocational tradition and focused on the technical skills necessary for work in industry (Drawing, Materials science, etc.) (Lgr 62 1962). It was nevertheless an important stepping stone to a more comprehensive technology subject. Some vocational teachers helped to transform the subject Technological orientation in the revision of the national curriculum in the mid-1960s, which led to creative and in many ways groundbreaking work on a curriculum for a comprehensive technological subject. As expressed in a document in the preparation of the new curriculum from August 1966: "The proposed Technological orientation contains important comprehensive knowledge [allmänbildning] and could foster technical thinking that would be valuable for all men" (PM från sakkunniga 1966, p. 4). In the 1969 curriculum (Lgr 69), it became the first subject ever in the Swedish school system with the name Technology and was optional for pupils at the lower secondary level together with Economics, art and modern languages (French or German).

The visions for the subject were therefore truly comprehensive and interdisciplinary in that the phenomenon and concept of technology itself became the centre, not primarily what was needed to be able to carry out a vocation. In this respect, any subject matter that could have relevance for technology was thought of and it was seen as the focal point of an interdisciplinary vision that included a wide range of other subjects, for instance, Mathematics, Biology, Physics, Chemistry, Swedish, Religion, History, Domestic science, Drawing and Educational sloyd. The focal point was divided into three central themes: technological product, technological process and technological service. It largely made up a model for the obligatory subject that emerged in 1980, together with items from, for example, Home geography and Natural science (PM från sakkunniga 1966; Lgr 69 1969; Cullert 1986).

Technology became a mandatory subject for all pupils in compulsory education at the lower secondary level (ages 13-16) in the 1980 national curriculum (Lgr 80), which was 
implemented in the autumn of 1982. The new subject, which was a quite remarkable addition in a historically very stable array of compulsory school subjects, was partly motivated by referring to the concept of allmänbildning/Bildung, although it seems not to have played a major role. According to Elgström and Riis (1990), one of the political goals of the new subject was for it to "increase technological literacy [allmänbildning] in an increasingly complex technological society" (p. 211). Other, perhaps more urgent, motives were to increase practical-technical elements in school, promote equality between boys and girls and strengthen the status of the natural science subjects in compulsory school (Elgström and Riis 1990). The latter motive was, according to Riis (2013), very likely the decisive one at a time when there was a perceived crisis due to the difficulty in recruiting young people to technical and science programs at the universities. Accordingly, the new subject of Technology was lumped together with the natural science subjects in the curriculum (cf. Lövheim 2010).

When the 1980 curriculum was being revised in the early 1990s, technology education appeared under the name "Technology and the Environment" (Teknik och miljö). It was therefore initially seen as a subject with connections to natural sciences as well as social sciences and issues of sustainability, albeit with its own identity as technology with other and older historical roots (SOU 1992:94; SOU 1993:2). The committee working on the revision, Läroplanskommittén, was more free from political constraints than was the case with the previous revision, and they established for the first time a subject-specific curriculum for technology. It was here defined as a knowledge domain in its own right, not dependent on the Natural sciences, and for the first time the subject was to be taught throughout compulsory school, from grade one to nine (Lövheim 2010; Carlgren 2013).

However, Biology teachers, for example, whose subject by tradition attached great weight to the environment, pointed out that environmental elements were too marginalised in the proposed subject (Fabricius and Landström 1993). In its bill, the Swedish government also emphasised that environmental issues were the responsibility of the whole of compulsory school, particularly science education. Furthermore, the government relied on comments from many societal actors that environmental issues could not only be connected to technology; the environmental theme was consequently dropped and the subject renamed Teknik, Technology (Prop. 1992/93:220). 
In the final 1994 national curriculum (Lpo 94), the technological Bildung/literacy argument was also revived and received a more prominent position, as the environmental elements became less central. Already in the fourth paragraph, one could read about the importance of pupils acquiring a "basic competence in technology" (Grundskolan, Kursplaner 1996, p. 91). This was then developed in the revision of 2000 :

Technical knowledge is increasingly becoming a prerequisite for mastering and using the technology surrounding us. Citizens in a modern society need basic competence in technology, and this competence must, in addition, be continuously expanded and adapted. This competence covers not only knowledge about the role of technological development from an historical perspective, but some experience in reflecting over and solving technical problems in practical terms. In addition, it is necessary to be able to analyse and evaluate the interaction between people, technology and the conditions under which we will exist in the future (Swedish Technology Curriculum 2000).

Central actors such as the Centre for School Technology Education (CETIS), which receives government grants for supporting school technology in various ways, also promoted the concept of teknisk bildning as a key component of what pupils should learn about technology in the early 2000s (see, e.g., Ginner 2007; 2008). In so doing, CETIS extrapolated arguments made in the 1994 national curriculum and the revision in 2000, but also mirrored a more recent discussion on technological literacy and teknisk bildning in the early $21^{\text {st }}$ century, both in Sweden and internationally (ITEEA 2000; Dakers 2006; Ingerman et al. 2009).

\section{The relationship between school technology and higher forms of technology education}

In Goodson's (1981) classic study on the genealogy of school subjects, building on work by Layton, he challenges the dominant theories on the origin of school subjects through the cases of Geography and Biology. Goodson claims that most theories of the time assumed school subjects to be reflections of knowledge originally developed by the dominant classes in society. Subjects like physics, chemistry, history and mathematics can be explained in this way. When introduced into public education, they were already established academic 
disciplines. He contrasts this "downward" force in the creation of school subjects by the way Geography and Biology were established as academic disciplines, namely, through starting out as low-status school subjects, and from these positions making "aspiration upwards", for academisation, and finally establishing themselves as high-status academic disciplines.

Aspiring to acquire high-status academic knowledge is a distinguishing aspect of school subjects, according to Goodson (1993, p. 35). Out of the three curriculum traditions that Goodson discerns in relation to public education - the academic, the utilitarian (an ability of a school subject to prepare one for future occupations) and the pedagogic (e.g., the progressive and child-centred tradition) - the former is of high status and the two latter of low status. Even though technology education today clearly aspires to high-status aspects, through linking its content to academic disciplines such as engineering, philosophy of technology and design, its content is not based on those disciplines. The same is true for engineering, philosophy of technology and design disciplines stemming from technology education.

Thus, the history of technology education displays other characteristics than the standard schemata suggested by Goodson, a kind of double-directed history in which high-status technological knowledge such as in engineering and low-status technological knowledge such as in primary technology education can be seen as coexisting and separate, but at times communicating and perhaps fusing, vessels. Although Goodson briefly notes the technical and practical traditions in school, and their "continuing subservience to the academic tradition", he does not recognise the role of academic traditions in the history of technology education (Goodson 1993, p. 24). In order to characterise technological knowledge as both a high-status and a low-status phenomenon, we will in the following present three historical examples.

The first example is taken from the late $19^{\text {th }}$ and early $20^{\text {th }}$ century. In this period, there was growing importance attached to the contemporary Swedish concept of teknik, which increasingly acquired a meaning similar to the present-day concept of technology. It mainly sprung out of the engineering profession and engineers' adoption of the concept as a way of denoting their area of expertise, in conjunction with developments in Germany. As early as 1871, the journal Teknisk tidskrift was established to spread technological knowledge to the 
lay public, although it soon developed into a journal mostly read by and directed at the engineers themselves. The journal was launched by the Swedish Association of Graduate Engineers (Svenska Teknologföreningen), which was established in the mid-19th century and has been Sweden's prime community for engineers and architects until this day. ${ }^{5}$ As a consequence of teknik being tied to the engineering profession, the concept became tightly linked to the male scene of industrial and mechanical inventions and to natural science (Oldenziel 1999, p. 20ff).

In Sweden, the strong industrial growth of the early 20th century influenced the content of the elementary curriculum in Sweden. When Educational sloyd was introduced in public schools in the late 19th century, the manual work of sloyd was seen as a way to foster moral character, but actors began, around the 1920s, to emphasize sloyd as a way to foster basic skills needed in a broad range of manual occupations in industrialising Sweden. Another example is Home geography (Hembygdskunskap), a subject introduced in 1919 for the first three grades, ages 7-10, aimed at introducing children to familiar objects, local trade and industry (Hallström 2009). However, the increased technological content of the elementary curriculum did not have its prime stakeholders among representatives at higher levels of technology education, but rather among the elementary teachers themselves. This promoted another type of technology education compared with that at secondary and higher levels. At the same time, it is evident that part of this development, especially the emphasis on the need for technological Bildung in primary education mentioned earlier, most probably would not have been possible if it had not been for the engineering profession having made the concept of teknik well known. In terms of communicating vessels, it is thus possible to talk about an influence, be it indirect, of the field of high-status technology on the technological content of primary schooling.

The second example is taken from the mid- $20^{\text {th }}$ century. During the post-war educational reforms in Sweden, technology education at all levels of the school system was strengthened. The overarching aim was to unify the school system. This called for new approaches to the content of schooling and challenged the borders between different levels

\footnotetext{
${ }^{5}$ From 1877-1974, it was called Svenska teknologföreningen, but today it is named Sveriges ingenjörer.
} 
and types of technology education. This especially affected the field of vocational training. Sweden, as many countries during these decades, was going through a radical transformation in the labour market with increasing productivity and a growing knowledgeintensive industry as well as unskilled work (Schön 2010, p. 322ff). What is more, too many pupils chose what politicians perceived to be the wrong paths in school, namely, the academically oriented paths. The problem of attracting pupils to vocational and general vocational programs therefore became of great concern for them. Upgraded vocational training was needed in order to make these programs more interesting choices for pupils (and their parents). It was in the efforts to make the vocational and general vocational fields of schooling more popular that the concept of teknik came to play a central role.

In a letter from the National Board of Education sent out in June 1960 to groups involved in the changes of primary and secondary education in Sweden at this time and that the Board saw as important for technology education (teknisk utbildning), among them the 1957 School Commission that had the specific task of designing the new nine-year compulsory school, the Board described how a technical sector had been tested in schools involved in the extensive trials (no sector with this name existed at this level of the school system prior to this), and that a particular programme of that sector had proven especially successful. This programme had a focus on mathematics, physics, chemistry and the Swedish language. It is interesting to note that, at this point, the Board explained that no technical subjects (tekniska fackämnen) were included in the programme, as such subjects would have made the program too specialised ( 4401960, p. 1). They also explained how this new program was supposed to fit in with the technological education planned for upper secondary level. The programme was to be linked to lower types of technology education, but not to higher studies in engineering. They requested that the groups addressed in the letter consider how this might affect their work. In the words of the Board:

With respect to the very large need for technically educated employees, the Board wants, again, to emphasise the importance of primary and secondary technology education [teknisk utbildning].

School authorities and other stakeholders in relation to technology education shall explore if the pre-training for upper secondary technology education is arranged in a 
satisfactory way and if parents and pupils are sufficiently informed about the possibilities that these types of educational paths offer (ibid., p. 3).

The letter from the Board had its intended effect. The 1957 Commission began developing a technical programme, and it was later implemented in the new compulsory school. However, despite the Board's emphasis on technical subjects being too specialised for compulsory education, we find a technical subject included in the programme: Technological orientation (Teknisk orientering). This subject included some general aspects of the fields of Applied mechanics, Technical drawing, Metalwork, Mechanics and Materials science (Lgr 62 1962 , p. 364ff). The subject was a last-minute construct and its status as a school subject was questioned from the very start. The Board claimed that the name was inappropriate, as "orientering" signalled that no proper knowledge was to be acquired in this subject (Utdrag ur Kungl. Skolöverstyrelsens utlåtande 1961, p. 37).

The establishment of a program in compulsory school named Technology and which contained a core subject also named Technology not only shows how the expanding sector of upper levels of technology education poured down and led to new demands of how to arrange these types of educational and vocational pathways at lower levels of the educational system, but also the growing importance of the term teknik (technology).

It was not only the compulsory school that saw new constructs in the area of technology education. A new subject called Teknologi was introduced in upper secondary technical education, tekniskt gymnasium, in 1966. Teknologi was "to provide pupils with basic knowledge in core subjects to the technical field by bringing knowledge material from several disciplines together and to emphasise the relationship between these" (SOU 1963:43, p. 413). The subject "contain[ed] a collection of the basic technical subjects of Mechanics, Solid mechanics, Technical drawing, Production and Materials science" (Engström and Malm 1966). Behind the development of Teknologi stood engineers involved in the construction of new upper secondary education. There were clear parallels between Teknologi and Teknisk orientering, not only in the fact that they were constructed around the same time, but also that this was partly by the same people.

The post-war expansion of technical education in Sweden created new technical subjects at secondary level. However, they were not constructed to build on one another, but to qualify 
pupils for different levels of technical occupations. In addition, they were not understood by those who constructed them as unified subjects, but as aggregations, subjects containing a suitable collection of technical sub-subjects. No unified notion of technological knowledge was developed, but these new subjects nonetheless triggered such a development in the years to follow.

In the first revision of the new nine-year compulsory school, Lgr 69, the optional courses were decreased to a choice in grade seven of one of four subjects: Technology (Teknik), Economics, Art and a third language (German or French). The fact that Teknik (Teknisk orientering had changed its name) was one of these four subjects was mostly due to the popularity of the field among pupils. On top of this, the aim of the optional courses became more generally oriented, as the vocational training that had been present in compulsory school was moved to upper secondary school. A more generally oriented technical subject, aimed at attracting all pupils including girls, was to be created. In this, the downward movement that created Teknisk orientering - the societal need for technologically trained students - came to be cross-fertilised by the broader tradition of primary technology. In this development, technology was turned into the object of study, but the content of the subject was also closely linked to other subjects in the curriculum (Hultén 2012). It was as if there was technology everywhere one looked in the "traditional" curriculum. Alternatively, as expressed in the Technology curriculum draft from December 1968:

The basic materials for teaching [in Teknik] are thus almost incalculable and cannot be defined because you cannot draw dividing lines between technology and other fields or between technical and non-technical products and tasks. The opaqueness of the teaching material increases with technological progress and developments in other areas (Förslag till kursplan 1968, p. 5).

This illustrates the scope of the concept of technology in a compulsory education context at that time. It also indicates a fluent boundary between different levels of technology education.

The third example is taken from the turn of the 21st century. In 2011, Teknik was included as a key subject in the upper secondary technical programme, as part of a newly reformed upper secondary school. The year before this, technology was included in the new national 
curriculum for pre-school (Lpfö 98, 2010). Parallel to this, there has been an increased interest in primary and secondary technology education among technical universities in Sweden. Technical universities such as the Royal Institute for Technology and Chalmers have been granted the right to award degrees of Master of Education in the technical field. This development has increased the need to reformulate technical knowledge on different levels of the school system and the need to address the progression of technological knowledge through the educational system. Engineering universities now have to address explicitly the question of what primary technological knowledge should be, as they are responsible for primary teacher training. Having said this, one must also note that the upper secondary school subject Teknik is still not required for tertiary engineering studies, although there are people, both teachers and engineers, who want to include it as such (cf. Goodson and the striving for academic status).

What finally transformed Geography and Biology into high-status academic fields were developments in science: in the case of Geography, these were new statistical methods, and in the case of Biology, they were the discovery of DNA and the experimental basis of Biology that this discovery brought to the field. Swedish technology education does not fit (at least not yet) into a history similar to Biology and Geography, where low status fields have been transformed to academic fields. Instead, technology education can be described as a history of two traditions, one utilitarian and pedagogical and of low status, the other academic and of high status. While the former has been associated with primary and lower secondary levels, the latter has typically been connected to engineering education. It is correct to say neither that primary technology education triggered the academic field of technology, nor that academic subjects such as engineering are the cause of primary technology. That is, primary technology could not be wholly explained by either an upward aspiration or a downward motion; rather, we see two relatively distinct fields in the history of Swedish technology education that have grown more and more interconnected.

\section{The relationship between technology and science}

In textbooks, syllabuses, policy documents and classroom practice, the contours of technology have always been more or less dependent on its relationship with science. 
Historical and sociological studies show that technology is sometimes separated and sometimes included within science, and that such recurring patterns can be understood as a result of boundary-working practices where status and epistemic authority are at stake (Gieryn 1999). The marking or blurring of the contours between school subjects - what is sometimes referred to as a classification process (Bernstein 1975) - is an important process to portray since it explains the visibility of technology as a school phenomenon and in what forms it appeared during the years 1842-2010.

In the early years of elementary schooling, textbooks in science included sections and headlines that demarcated "technologie" as a phenomenon worthy of its own classification. To a large part, these descriptions represented a practical knowledge tradition with reference mostly to everyday needs. The above-mentioned example of J.F. Schlez from 1846 and the basic understanding of glass serve as an illustrative point. Within sections such as "technologie", it was thus possible to find arguments for technology as a necessary perspective to have in order for pupils to understand necessary aspects of everyday life (Hultén 2008; Schlez 1846; Hartman 1836).

In the decades around the turn of the $20^{\text {th }}$ century, such boundaries of technologywithin-science became less articulated. The sections and headlines that marked technology as a special phenomenon were taken away. This development coincided in time with scientists abandoning textbook writing - instead the enterprise was picked up by elementary school teachers. In these textbooks, the practical knowledge tradition was downplayed and instead the portrayal of technology as "applied science" became sharpened. The example of milk production is illustrative in this regard. In the 1850s, this process was described in detail and gave insight into the ordinary life of pre-industrial society. However, in 1913, the same chapter was cut and made much more abstract. In this way, it became more distant from the early agrarian setting (Berlin 1913; Hultén 2011). This marked a somewhat different understanding of the primary source of technological knowledge. The earlier practical knowledge tradition was gradually replaced by an assumption of science as the primary source of the development of technology. Coinciding with this change was a heavier emphasis on modern technology and less on traditional and well-established practical improvements (Berner 1997; Oldenziel 1999). 
If the contours of technology were made less visible in textbooks, this was also the case in terms of curricula at the end of the $19^{\text {th }}$ century. As the older curricula of elementary science were reformed, the presence of modern technology was constantly updated as an illustration of applied science. For example, the lever and the thermometer from 1878 were supplemented in 1900 with the telephone and the telegraph (Hallström 2007).

Put differently, in the wake of scientific progress, the classification of technology in teaching materials was weakened in its relationship to science. The close relationship was maintained during the first part of the $20^{\text {th }}$ century. Something that contributed to the blurring of borders of technology was the fact that parts of technological contents appeared in other subjects during the period 1900 to 1950. Among these were Educational sloyd (Craft), Home geography, Domestic science and Gardening (Hallström 2009; Lövheim 2010).

In the second part of the $20^{\text {th }}$ century, this rather scattered situation slowly started to change and the presence of technology in the curriculum gradually became more distinct. Owing to the growing impact of technology in post-war society, different projects were started in order to increase its presence in schools. In the early 1960s, an optional technology subject was created. The character of the course was vocational and attracted mostly boys. In the latter part of the 1960s, this course attracted a lot of attention owing to its popularity, and its content was subject to discussion. A reformulated technology subject was thus created in the late 1960s, Teknik. Instead of a vocational character, this was framed as a general school subject. In this, the content of the subject was related to the technological content present in other subjects, thus connecting to the technological tradition in elementary school.

In the latter half of the 1970s, governmental decisions made clear that technology had become so important that it was to be made compulsory. The process of constructing the new subject matter, however, became a reminder of technology's rather vague identity in the past. Was it to be a subject completely in its own right or should it be placed within another discipline? If so, where did it belong? Was there a natural haven for technology? Two subjects - Sloyd and Science - crystallised as contenders in a battle of who was to host technology. After more than a year of tug-of-war, it was finally decided that Technology would be placed with Science. The government bill stated: 
International studies have emphasised the importance of treating science and technology as a single entity in teaching. This entity has to be obvious for pupils both at the start and at the end of a chapter. Theory and application also have to be intimately united. A teaching process that does not constantly accentuate this unity has not fulfilled its purpose (Prop. 1978/79:180, p. 76).

As a consequence, the boundaries of the subject can be said to have become both clear and vague at the same time. Technology was still relatively weakly classified in relation to Science. However, in the matter of belonging to Science and not to Sloyd, it had a stronger classification than before (Lövheim 2010).

The demarcation of the late 1970s was being challenged in the early 1990s. The belonging to Science was problematised for epistemological reasons as a new committee defined technology as something completely independent. Here, technological knowledge was portrayed as different from its scientific equivalent. A considerable amount of effort was being expended in the epistemologically motivated separation from Science. The parliamentary report preceding the new Technology curriculum of 1994 stressed the notion of, "an independent area of knowledge with a considerable element of practical experience and craftsmanship" (Lpo 94 1994, p. 252).

In this way, the boundaries of the 1990s resembled the textbooks in the mid-19 ${ }^{\text {th }}$ century as they classified Technology as a more clearly defined entity. However, in the 1990s, the arguments were much more elaborate and the work of the committee also used a certain historic perspective that provided support for the separation of the two disciplines of science and technology. In the inner workings of the committee, this historic perspective was being formulated as follows:

Historically speaking it is a matter of two totally different areas of knowledge. Humans had for example extracted and worked with iron long before there was a theory that explained these procedures. The learned of old times used spectacles before Kepler formulated the basics for geometrical optics. It is only in recent years that scientific achievements have led to an ever increasing number of applications (Kursplanearbete i naturvetenskap, vol. 2). 
This separation of Science and Technology within the curriculum was maintained in the last curriculum reform, in 2011. However, in practice in the classroom, "a hegemony of science" has dominated teaching, treating technology as applied science or mainly scientific aspects of technology (Klasander 2010). This persistent form of a boundary that encapsulates Technology within Science is also present in important educational policy texts in Sweden. Here, the discursive clustering of the two disciplines is still frequently used, something that can be said to counter the definition of technological knowledge as something with boundaries of its own (Teknikdelegationen 2010; Lövheim 2013).

\section{Concluding discussion}

This study is the result of a double-sided approach to technological knowledge, studied both through the history of school subjects and as a technological educational entity more generally. Most previous studies on the history of technological education have been restricted either to the more recent history of technological school subjects or to their most obvious predecessors (Industrial arts, Arbeitslehre, Educational sloyd). School subjects, however, often have older and more complex histories than can be captured by such approaches. As Goodson has pointed out:

[S]ubjects are not monolithic entities but shifting amalgamations of subgroups and traditions which through contestation and compromise influence the direction of change (Goodson 1994, p. 42).

We argue that the approach developed in this study can meet the complicated task of capturing a more comprehensive history of school subjects as "shifting amalgamations of subgroups and traditions" rather than as "monolithic entities". We want to stress the importance of including broader pictures for understanding different knowledge traditions. In our study, we have not restricted the focus to certain school forms, but have instead tried to understand technological knowledge traditions in light of what happened at other levels in the educational system or in society as a whole (cf. Hallström 2011). However, in unmasking the often complex web of intersecting developmental traits, one must not forget that certain creations and solutions are not always as intentional as we may want them to 
be; the fact that Sweden has a separate subject called Teknik is not only a result of practical knowledge traditions and strategic actors, but also of ad hoc solutions and last-minute constructs.

In conclusion, technology was connected to the concept of Bildung/bildning early on in the $20^{\text {th }}$ century, thus forming an early version of technological literacy with a focus on technology as a central aspect of shaping educated Swedish citizens. Furthermore, technology became intertwined with democratic issues as Sweden was simultaneously democratised and industrialised in the first decades of the $20^{\text {th }}$ century. Parallel to this, technology became increasingly visible in several elementary school subjects such as Home geography, Natural science and Educational sloyd from the 1920s onward. In the 1960s, technology became a separate subject in the new compulsory school, first as Technological orientation and in 1969 as Technology. The optional Technology subject of 1969 was a truly interdisciplinary subject that connected to almost all other subjects. When Technology became a mandatory subject for all children in compulsory school in 1980, it was, however, again associated with the natural sciences.

Still no "monolithic entity", technology education in Swedish compulsory school today is "communicating" with the diverse historical roots outlined in this study. Elements from a vocational tradition, natural and social sciences as well as a more recent techno-historical tradition shape the subject at the specific curriculum level as well as at the enacted level in classrooms, where teachers also bring practices from their own teacher education and the other subjects they teach into technology education (Banks \& McCormick 2006). As a result, Technology is still no firmly established subject and has a low status. There is good reason to believe that the difficulty for technology education worldwide to establish itself as a unified knowledge tradition and curriculum area in schools has to do with it being a combination of varied and sometimes incompatible historical knowledge traditions (cf. McCulloch et al. 1985; de Vries and Mottier 2006), something that can be useful to take into consideration for today's "subgroups and traditions" when shaping technology education in the days to come.

\section{References}


Arthur, W. B. (2009). The Nature of Technology: What It Is and How It Evolves. New York: The Free Press.

Banks, F. \& McCormick, R. (2006). A case study of the inter-relationship between science and technology: England 1984-2004. In M. J. de Vries \& I. Mottier (Eds.), International Handbook of Technology Education: Reviewing the Past Twenty Years. Rotterdam \& Taipei: Sense Publishers.

Barton, K. C. (2009). Home Geography and the Development of Elementary Social Education, 1890-1930. Theory and Research in Social Education, 37(4), 484-514.

Berlin, N. J. (1913). Lärobok i naturlära för folkskolan. Efter skolans nuvarande krav omarbetad av Sven Leonhard Törnquist. Lund.

Bernstein, B. (1975). Class, Codes and Control. Vol. 3, Towards a theory of educational transmissions. London: Routledge \& Keegan Paul.

Blomkvist, P. \& Kaijser, A. (1998). Den konstruerade världen. Tekniska system i historiskt perspektiv Eslöv: Symposion.

Centervall, A. (1932). Hyser vårt folk intresse för teknisk bildning? Tidskrift för föreläsningsverksamheten, 8(1), 5-6.

Chafy, R. (1997). Exploring the Intellectual Foundation of Technology Education: From Condorcet to Dewey. Journal of Technology Education 9(1), 6-19.

Cullert, B. (1986). Med folkskolans pedagogik som riktmärke. Minnesanteckningar från grundskolans tillkomst och första årtionde. Stockholm.

Carlgren, I. (2013). Hurusom teknik kom att skiljas från naturvetenskap i "Skola för bildning". In J. Hallström \& C. Klasander (Eds.), The Ginner Handbook of Technology Education: Some Theses about Technology, School and Society. Norrköping: Linköping University, Centre for School Technology Education.

Dakers, J. R. (Ed.) (2006). Defining Technological Literacy: Towards an Epistemological Framework. New York: Palgrave Macmillan. 
de Vries, M. J. \& Mottier, I. (Eds.) (2006). International Handbook of Technology Education: Reviewing the Past Twenty Years. Rotterdam: Sense Publishers.

Elgström, O. \& Riis, U. (1990). Läroplansprocesser och förhandlingsdynamik. Exemplet obligatorisk teknik i grundskolan. Linköping: Tema, Univ.

Elzinga, A., Jamison, A. \& Mithander, C. (1998). Swedish Grandeur: Contending Reformulations of the Great-Power Project. In M. Hård \& A. Jamison (Eds.), The Intellectual Appropriation of Technology: Discourses on Modernity, 1900-1939. Cambridge, MA and London: MIT Press.

Engström, S. \& Malm, K. (1966). Teknologi : Gymnasiet År 1 Och 2 : Lärarhandledning. Stockholm: SÖ-förlaget.

Fabricius, S. \& Landström, L.-E. (1993). Härmed överlämnar Biologilärarnas förening (BF) sitt remissyttrande över Kursplaner för grundskolan (SOU 1993:2). Biologen, 60(2), 21-23.

Foster, P. N. (2011). Genesis and Early Evolution of the Yearbook Series of the American Council on Industrial Arts Teacher Education. Journal of Technology Education, 22(2), 22-41.

Förslag till kursplan med anvisningar och kommentarer i tillvalsämnet teknik 1968-12-12 (1968). Available from The National Archives (Riksarkivet). Archive: Läroplansarbete för grundskolan, Lgr 69. Archive number: Skolöverstyrelsens arkiv, SE/RA/420262/29/F I a, vol. 6.

Gieryn, T. F. (1999). Cultural boundaries of science: credibility on the line. Chicago: University of Chicago Press.

Ginner, T. (2007). Törs vi tala om teknisk bildning? Tekniken i skolan. Nyhetsbrev för teknikämnet i förskola och skola, 13(4), 1-3.

Ginner, T. (2008). Teknisk bildning - vad skulle det kunna betyda? Tekniken i skolan. Nyhetsbrev för teknikämnet i förskola och skola, 14(1), 1-2.

Goodson, I. (1981). Becoming an Academic Subject: Patterns of Explanation and Evolution. British Journal of Sociology of Education, 2(2), 163-180.

Goodson, I. (1993). School Subjects and Curriculum Change: Studies in Curriculum History (Third ed.). London, New York: RoutledgeFalmer. 
Goodson, I. (1994). Studying Curriculum. Cases and Methods. Buckingham: Open University Press.

Grundskolan. Kursplaner. Betygskriterier. (1996). Stockholm: Skolverket.

Hallström, J. (2007). Elementary School Technology Education in Sweden, ca. 1900-1920. In John R. Dakers, Wendy J. Dow \& Marc J. de Vries (Eds.), PATT 18 Pupils' Attitudes Towards Technology, International Conference on Design and Technology Educational Research, 2007, Teaching and Learning Technological Literacy in the Classroom. Glasgow: Faculty of Education, University of Glasgow.

Hallström, J. (2009). Technical Knowledge in a Technical Society: Elementary School Technology Education in Sweden, 1919-1928. History of Education 38(4), 455-474.

Hallström, J. (2011). Looking Back in Order to Move Forward: The Position of Technology Education in Past Swedish Curricula. In M. J. de Vries (Ed.), Positioning Technology Education in the Curriculum. Rotterdam: Sense Publishers.

Hallström, J., Hultén, M. \& Lövheim, D. (Eds.) (2013). Teknik som kunskapsinnehåll i svensk skola 1842-2010. Möklinta: Gidlunds.

Hartman, C. J. (1836). Utkast till populär naturkunnighet : Ett försök till lärobok för de lägre undervisningsverken. Stockholm: Zacharias Haeggström.

Hansson, S. (2002). Den skapande människan. Om människan och tekniken under 5000 år. Lund: Studentlitteratur.

Helger, N. (1930/1935). Medborgarbok för ungdomsskolor. 19th/25th ed. Uppsala: J. A. Lindblads förlag.

Herschbach, D. R. (1996). "What Is Past Is Prologue": Industrial Arts and Technology Education. Journal of Technology Studies, 22(1), 28-39.

Hughes, T. P. (1987). The Evolution of Large Technological Systems. In W. E. Bijker, T. P. Hughes \& T. J. Pinch (Eds.), The Social Construction of Technological Systems: New Directions in the Sociology and History of Technology. Cambridge, Mass.: MIT Press, cop. 
Hughes, T. P. (2004). Human-Built World: How to Think About Technology and Culture. Chicago: University of Chicago Press.

Hultén, M. (2008). Naturens kanon. Formering och förändring av innehållet i folkskolans och grundskolans naturvetenskap 1842-2007. Stockholm: Stockholm University.

Hultén, M. (2011). Läroboken som medel för professionalisering: exemplet med naturvetenskapliga läromedel skrivna för den svenska folkskolan under 1800-talett. In D. Skjelbred \& B. Aamotsbakken (Eds.), Norsk Lærebokhistorie III: en kultur- og danningshistorie. Oslo: Novus forlag.

Hultén, M. (online 2012). Technology as the language of schooling: utopian visions of technology in Swedish general education in the 1960s. International Journal of Technology and Design Education. DOI: 10.1007/s10798-012-9205-9.

Hård, M. \& Jamison, A. (2005). Hubris and Hybrids: A Cultural History of Technology and Science. New York: Routledge.

Högnäs, S. (2001). The Concept of Bildung and the Education of the Citizen: Traits and Developments in the Nordic Countries 1870-2000. In S. Ahonen \& J. Rantala (Eds.), Nordic Lights: Education for Nation and Civic Society in the Nordic Countries, 1850-2000. Helsinki: Finnish Literature Society.

| 440: Riktlinjer rörande den förberedande och därpå byggande tekniska utbildningen. 196007-29 (1960). Available from The National Archives (Riksarkivet). Archive: 1957 års skolberedning. Archive number: SE/RA/321818/27.

Ingelstam, L. (1978). Teknikpolitik. En bok om tekniken, människan och socialismen. Stockholm: Tiden förlag.

Ingelstam, L. (2013). Tekniken i politiken. Tankar från tåget. In J. Hallström \& C. Klasander (Eds.), The Ginner Handbook of Technology Education: Some Theses about Technology, School and Society. Norrköping: Linköping University, Centre for School Technology Education.

Ingerman, Å., Wagner, K. \& Axelsson, A.-S. (Eds.) (2009). På spaning efter teknisk bildning. Stockholm: Liber. 
Jenkins, E. (1997). Technological literacy: Concepts and constructs. Journal of Technology Studies, 23(1), 2-5.

Klasander, C. (2010). Talet om tekniska system. Förväntningar, traditioner och skolverkligheter. Norrköping, Linköping University.

Kursplanearbete i naturvetenskap och teknik för grundskolan, PM nummer 2. Available from The National Archives (Riksarkivet). Archive: Läroplanskommitténs arkiv. Archive number: SE/RA/324265.

Latour, B. (1987). Science in Action: How to Follow Scientists and Engineers through Society. Cambridge, MA: Harvard University Press.

Latour, B. (1999). Pandora's Hope: Essays on the Reality of Science Studies. Cambridge, MA: Harvard University Press.

Layton, D. (Ed.) (1994). Innovations in Science and Technology Education Vol. V. Paris: UNESCO.

Lindqvist, S. (1987). Vad är teknik? In B. Berner \& B. Sundin (Eds.), I teknikens backspegel. Antologi i teknikhistoria. Stockholm: Carlssons.

Läroplan för förskolan, Lpfö 98 : Reviderad 2010 (2010). Stockholm: Skolöverstyrelsen.

Läroplan för grundskolan, Lgr 62 (1962). Stockholm: Skolöverstyrelsen.

Läroplan för grundskolan, Lgr 69. I Allmän del (1969). Stockholm: Skolöverstyrelsen.

Läroplan för det obligatoriska skolväsendet, Lpo 94 (1994). Stockholm: Skolverket.

Lövheim, D. (2010). An epistemology of one's own: Curricular (re)construction of school technology and non-technology in Sweden, 1975-1995. History of Education, 39(4), 525537.

McCulloch, G., Jenkins, E. \& Layton, D. (1985). Technological Revolution? The Politics of School Science and Technology in England and Wales Since 1945. London: Falmer Press.

McCulloch, G. (1987). School Science and Technology in Nineteenth and Twentieth Century England: A Guide to Published Sources. Studies in Science Education, 14(1), 1-32. 
Mellström, U. (2009). Män i teknikens värld. In P. Gyberg \& J. Hallström (Eds.), Världens gång

- teknikens utveckling. Om samspelet mellan teknik, människa och samhälle. Lund: Studentlitteratur.

Mitcham, C. (1994). Thinking through technology: The Path between Engineering and Philosophy. Chicago: University of Chicago Press.

Nordisk familjebok, 15. Socker - Tengström. (1891). http://runeberg.org/nfao/0764.html. Accessed October 10, 2010.

Nordisk familjebok, Uggleupplagan, 28. Syrtenvikarna - Tidsbestämning. (1919). http://runeberg.org/nfch/0371.html. Accessed October 10, 2010.

Oldenziel, R. (1999). Making technology masculine: Men, women and modern machines in America 1870-1945. Amsterdam: Amsterdam University Press.

Pannabecker, J. R. (1994). Diderot, the Mechanical Arts, and the Encyclopédie: In Search of the Heritage of Technology Education. Journal of Technology Education, 6(1), 45-57.

Pannabecker, J. R. (1995). For a history of technology education: Contexts, systems, and narratives. Journal of Technology Education, 7(1), 43-56.

Petrina, S. (1998). The Politics of Research in Technology Education: A Critical Content and Discourse Analysis of the Journal of Technology Education, Volumes 1-8. Journal of Technology Education, 10(1), 27-57.

PM från sakkunniga i ämnesgruppen för hemkunskap och barnavård i samband med översyn av grundskolans läroplan (1966). Available from The National Archives (Riksarkivet). Archive: Läroplansarbete för grundskolan, Lgr 69. Archive number: SE/RA/420262/29/F I a, Vol. 2.

Prop. 1978/79:180 (1978). Om läroplan för grundskolan m. m. http://www.riksdagen.se/sv/Dokument-Lagar/Forslag/Propositioner-och-skrivelser/prop197879180-om-laroplan-f_G203180. Accessed 10 June 2013.

Prop. 1992/93:220 (1992). En ny läroplan för grundskolan och ett nytt betygssystem för grundskolan, sameskolan, specialskolan och den obligatoriska särskolan. 
http://data.riksdagen.se/fil/104C3D36-1002-43B2-AB1C-F13DCAE2717E. Accessed 22 May 2013.

Riis, U. (2013). Teknik - mellan slöjd och naturvetenskap. In J. Hallström \& C. Klasander (Eds.), The Ginner Handbook of Technology Education: Some Theses about Technology, School and Society. Norrköping: Linköping University, Centre for School Technology Education.

Rudolph, J. L. (2008). Historical Writing on Science Education: A View of the Landscape. Studies in Science Education, 44(1), 63-82.

Rydén, V. \& Thomson, A. (1935). Medborgarkunskap för fortsättnings- och andra ungdomsskolor. 7th ed. Stockholm: Norstedts.

Schatzberg, E. (2006). Technik Comes to America: Changing Meanings of Technology before 1930. Technology and Culture, 47(3), 486-512.

Schlez, J.F. (1846). Populär naturkunnighet: En läse- och lärobok för folkskolor. Stockholm.

Schön, L. (2010). Sweden's road to modernity: An economic history. Stockholm: SNS Förlag.

Standards for Technological Literacy: Content for the Study of Technology (2000). Reston, VA: International Technology Education Association. http://www.iteaconnect.org/TAA/PDFs/xstnd.pdf. Accessed 6 September 2006.

Swedish Government Official Report. SOU 1963:43. Läroplan för gymnasiet. 1960 års gymnasieutredning V. Stockholm.

Swedish Government Official Report. SOU 1992:94. Skola för bildning. Huvudbetänkande av läroplanskommittén. Stockholm: Allmänna förlaget.

Swedish Government Official Report. SOU 1993:2. Kursplaner för grundskolan. Slutbetänkande av läroplanskommittén. Stockholm: Allmänna förlaget.

Swedish Government Official Report. SOU 2010:28. Teknikdelegationens betänkande Vändpunkt Sverige - ett ökat intresse för matematik, naturvetenskap, teknik och IKT. Stockholm. 
Swedish Technology Curriculum. (2000). Stockholm: Skolverket. http://www3.skolverket.se/ki03/front.aspx?sprak=EN\&ar=1213\&infotyp=23\&skolform=11\&i d=2089\&extrald=2087. Accessed 17 May 2013.

Utdrag ur Kungl. Skolöverstyrelsens utlåtande över 1957 års skolberednings betänkande (1961). Stockholm: Skolöverstyrelsen.

Vår praktiska bildningslinje. Folkskolan som bottenskola. (1902). Svensk Läraretidning, 21(27), 492.

Zuga, K. F. (1997). An Analysis of Technology Education in the United States Based Upon an Historical Overview and Review of Contemporary Curriculum Research. International Journal of Technology and Design Education, 7(3), 203-17. 